\title{
Feeding strategy during pregnancy for ewes with a large litter size. 1. Effect of quantity and composition of concentrates on intake and reproductive performance
}

\author{
H. EVERTS \\ Research Institute for Livestock Feeding and Nutrition, P.O. Box 160, NL 8200 AD Lelystad, \\ Netherlands
}

Received 7 December 1989; accepted 9 January 1990

\begin{abstract}
In six feeding trials with pregnant crossbred ewes the effect of four different feeding regimes on intake (dry matter, energy and crude protein), reproductive performance and occurence of acetonaemia were compared. The treatments differed in energy level, protein supply, protein degradability and the level of concentrates supplementation. Hay was used as roughage. The mean litter size was 3.26 . The sum of the birth weights of lambs was positively affected by the treatment where a higher protein level was combined with a lower degradability of the protein. Net body weight gain was affected by litter size, occurence of acetonaemia and treatment. The ME-intake was in general lower than the aimed levels. Treatments with $60 \%$ of energy originating from concentrates showed a higher ME intake then treatments with $40 \%$ of energy originating from concentrates. The crude protein intake was higher on the treatment where a higher protein level was combined with a lower degradability. Dry matter intake in the last two months of pregnancy was affected by litter size, age of the ewes, occurence of acetonaemia and feeding treatment. Dry matter intake decreased in the last weeks of pregnancy. This decrease was related to litter size. The possible reasons for this effect are discussed. Substitution rates of concentrates to forage depended also on the litter size. The effect of the acetonaemia on the intake pattern is described.
\end{abstract}

Keywords: ewe, pregnancy, feeding strategy, dry matter intake, energy, protein degradability, litter size, acetonaemia

\section{Introduction}

To improve the financial outcome of sheep farming in the Netherlands an increase in the number of weaned lambs per ewe per year is needed. Crossbreeding is one of the methods to increase litter size, especially when high fertility and good meat quality coincide. To prevent a high incidence of acetonaemia and a high lamb mortality at lambing, an increase in litter size demands an adjusted feeding to meet the 
higher requirements. About the effect of litter size on feed intake varying results are reported. A limited feed intake by ewes with twins compared to ewes with singles is observed by Reid (1961), feeding a mixture of lucerne and wheat chaff. This was also found by Tissier et al. (1975) and Orr et al. (1983) on roughage diets supplemented with concentrates. On a diet of only hay Orr \& Treacher (1984) observed a lower feed intake of ewes with triplets and quadruplets compared to ewes with twins. However, an effect of litter size on feed intake was not observed by Foot \& Russel (1979) on a hay or dried grass diet. Also Dittrich et al. (1980a, b) showed no difference in feed intake between ewes with twins, triplets or quadruplets on dried grass or on a pelleted diet.

The effect of stage of pregnancy on feed intake is often described. A decreasing feed intake during the last weeks of pregnancy was shown by Reid (1961), Tissier et al. (1975), Orr \& Treacher (1984), Dittrich et al. (1980a, b) and by Tissier \& Brelurut (1979). Stern et al. (1978) observed also a dramatic decrease in intake at the end of pregnancy in fat ewes. The level of feed intake at the end of pregnancy varied widely between the experiments from literature. This was probably due to effects of difference in breed of the sheep, quality of the ration, climatological condition and type of diet (complete diet or roughage supplemented with concentrates). Also the age of the ewes can affect dry matter intake as shown by Tissier et al. (1975).

Especially for ewes with three or more lambs, data about the effect of litter size on feed intake at the end of pregnancy are limited and conflicting. An optimum feeding strategy for ewes with a large litter size should result in a sufficient feed intake, a minimal incidence of acetonaemia and vital lambs at birth. Therefore several feeding strategies were compared to the Dutch feeding standards for ewes with twins. The effect of the treatments on feed intake, incidence of acetonaemia, lamb birth weight and perinatal lamb mortality was studied in six feeding trials with pregnant crossbred ewes. In the first and second year the effect of a high feeding level during mid pregnancy was studied. In the third and the fourth year the effect of a higher proportion of energy originating from concentrates at the end of pregnancy and in the fifth and sixth year the effect of a higher proportion of energy from concentrates combined with a higher protein supply and a lower protein degradability at the end of pregnancy was studied.

\section{Material and methods}

\section{Treatments}

The control treatment ( $=\mathrm{L} 40 \mathrm{C}$ ) was comparable to the Dutch feeding standards for ewes with twins. During mid pregnancy the feeding level was low and at the end of pregnancy about $40 \%$ of the energy was originating from concentrates. Treatment $\mathrm{H} 40 \mathrm{C}$ was the same as the treatment $\mathrm{L} 40 \mathrm{C}$, but the feeding level was increased during mid pregnancy and the concentrate had a reduced protein content. Treatment L60C had a more gradually increasing pattern of feeding. At the end of pregnancy the feeding level was higher than on the control treatment $\mathrm{L} 40 \mathrm{C}$ and about 
$60 \%$ of the energy was originating from concentrates. Treatment L60C $+\mathrm{P}$ was the same as treatment $\mathrm{L} 60 \mathrm{C}$, but the concentrate had a higher protein content and the protein was less degradable due to the inclusion of potato protein.

\section{Animals}

In October of the six experimental years about 40 crossbred ewes (Ile de France $x$ Finnish Landrace; aging from 2 to 8 years) were mated by Texel rams after oestrus synchronisation. The day of mating was counted as day 0 of the pregnancy. Comparable groups of ewes were formed, taking into account age, live weight, body condition and lamb production in previous years. The groups of ewes were allotted to the treatments. The number of ewes on the treatments in the experimental years is shown in Table 1.

Fortnightly the ewes were weighed and scored for their body condition (Jefferies, 1961). After lambing, ewes and the born lambs were weighed. The results of barren ewes and the data from macerated and mummified lambs were excluded from the calculations. After lambing, two lambs remained with the mother and the surplus was reared artificially.

\section{Feeding and feedstuffs}

The individually penned and fed ewes were offered hay twice daily. Concentrates were offered twice daily, when the allowance was higher than 200 gram per day. Hay refusals were collected twice weekly, but concentrates refusals daily. Mean chemical composition, calculated metabolizable energy (ME), calculated digestible crude protein (DCP) and in vitro digestibility of the organic matter $\left(\mathrm{d}_{\mathrm{O}}\right)$ of the feeds are shown in Table 2 . The rations for the ewes were calculated according to their metabolic body weight $\left(=\mathrm{W}^{3 / 4}\right)$. The aimed ME and concentrates allowance is shown in Table 3. The difference between the total ME and ME from concentrates was fed as hay. In the last months of pregnancy hay was offered at a level of $115 \%$ of the calculated amount in the ration.

Table 1. Number of ewes per treatment.

\begin{tabular}{lcccc}
\hline Year & \multicolumn{2}{l}{ Treatment } & & \\
\cline { 2 - 5 } & L40C & H40C & L60C & L60C+P \\
$1979 / 1980$ & 16 & 17 & - & - \\
$1980 / 1981$ & 18 & 20 & - & - \\
$1981 / 1982$ & 19 & - & 21 & - \\
$1982 / 1983$ & 18 & - & 19 & 19 \\
$1983 / 1984$ & 16 & - & - & 19 \\
$1984 / 1985$ & 18 & 37 & 40 & 38 \\
Total & 105 & 37 & \\
\hline
\end{tabular}




\section{H. EVERTS}

Table 2. Mean chemical composition ( $\left.\mathrm{kg}^{-1}\right)$, calculated ME (MJ kg-1), calculated DCP $\left(\mathrm{g} \mathrm{kg}^{-1}\right)$ and the in vitro digestibility $(\%)$ of the organic matter $\left(\mathrm{d}_{0 \mathrm{t}}\right)$ of the feeds in the dry matter.

\begin{tabular}{|c|c|c|c|c|c|c|}
\hline \multirow[t]{2}{*}{ Hay } & \multicolumn{6}{|l|}{ Year } \\
\hline & $79 / 80$ & $80 / 81$ & $81 / 82$ & $82 / 83$ & $83 / 84$ & $84 / 85$ \\
\hline Dry matter & 873 & 872 & 895 & 892 & 877 & 863 \\
\hline Ash & 95 & 110 & 111 & 114 & 90 & 111 \\
\hline Crude protein & 178 & 190 & 226 & 222 & 151 & 217 \\
\hline Crude fibre & 242 & 265 & 236 & 265 & 308 & 286 \\
\hline Metabolizable energy & 10.8 & 9.8 & 10.4 & 9.2 & 8.7 & 9.6 \\
\hline Digestible crude protein & 132 & 131 & 161 & 160 & 95 & 159 \\
\hline \multicolumn{7}{|c|}{$\begin{array}{l}\text { Digestibility of organic matter } \\
\text { in vitro }\end{array}$} \\
\hline \multirow[t]{2}{*}{ Concentrates } & \multicolumn{6}{|c|}{ Treatment } \\
\hline & $\mathrm{L} 40 \mathrm{C}$ & $\mathrm{H} 40 \mathrm{C}$ & L60C & \multicolumn{3}{|c|}{$\mathrm{L} 60 \mathrm{C}+\mathrm{Pl}$} \\
\hline Dry matter & 882 & 877 & 885 & \multicolumn{3}{|l|}{880} \\
\hline Ash & 93 & 64 & 68 & \multicolumn{3}{|l|}{66} \\
\hline Crude protein & 196 & 91 & 189 & \multicolumn{3}{|l|}{240} \\
\hline Crude fibre & 111 & 63 & 82 & \multicolumn{3}{|l|}{84} \\
\hline Crude fat & 44 & 27 & 56 & \multicolumn{3}{|l|}{58} \\
\hline Metabolizable energy & 12.6 & 13.1 & 13.6 & \multicolumn{3}{|l|}{13.5} \\
\hline Digestible crude protein & 154 & 51 & 154 & \multicolumn{3}{|l|}{199} \\
\hline
\end{tabular}

1 In the concentrate of treatment $\mathrm{L} 60 \mathrm{C}+\mathrm{P}$ one third of the protein is potato protein with a low degradability.

\section{Statistical analysis}

The results were analysed with a multiple regression using the model:

$$
\mathrm{Y}_{\mathrm{ijklm}}=\mu+\mathrm{A}_{\mathrm{i}}+\mathrm{B}_{\mathrm{j}}+\mathrm{C}_{\mathrm{k}}+\mathrm{D}_{\mathrm{l}}+\mathrm{E}_{\mathrm{m}}+\mathrm{e}_{\mathrm{ijklm}}
$$

where:

$$
\begin{array}{ll}
\mu & =\text { mean } \\
A_{i}(i=1,6) & =\text { effect of year of experiment ('79/' } 80-' 84 / ' 85) \\
B_{j}(j=1,5) & =\text { effect of litter size (1-5 lambs) } \\
C_{k}(k=1,2) & =\text { effect of age (two years or older) } \\
D_{1}(l=1,2) & =\text { effect of acetonaemia (acetonaemia or not) } \\
E_{m}(m=1,4) & =\text { effect of treatment (L40C, H40C, L60C, L60C }+P) \\
e_{i j k l m} & =\text { error component }
\end{array}
$$

In the experiments always one treatment was compared to the control treatment L40C in the same year. Using the given model effects of treatments and of years can be mixed. But analysis of the data per tested combination of treatments using the same model without the effect of year gave hardly different estimates for the differences between control L40C and treatments. Not normally distributed charactaristics are tested with the $\chi^{2}$ test. 
Table 3. The aimed feeding level (MJ ME $\mathrm{W}^{-3 / 4}$ ) and the level of concentrate supplementation (= conc.) in $\mathrm{g} \mathrm{W}^{-3 / 4}$ in the different treatments.

\begin{tabular}{|c|c|c|c|c|c|c|c|c|}
\hline \multirow{3}{*}{$\begin{array}{l}\text { Days of } \\
\text { pregnancy }\end{array}$} & \multicolumn{8}{|c|}{ Treatment } \\
\hline & \multicolumn{2}{|c|}{$\mathrm{L} 40 \mathrm{C}$} & \multicolumn{2}{|c|}{$\mathrm{H} 40 \mathrm{C}$} & \multicolumn{2}{|c|}{$\mathrm{L} 60 \mathrm{C}$} & \multicolumn{2}{|c|}{$\mathrm{L} 60 \mathrm{C}+\mathrm{P}$} \\
\hline & $\mathrm{ME}$ & conc. & $\mathrm{ME}$ & conc. & $\mathrm{ME}$ & conc. & $\mathrm{ME}$ & conc. \\
\hline $0-40$ & 0.35 & 2.5 & 0.35 & 2.5 & 0.35 & 2.5 & 0.35 & 2.5 \\
\hline $40-84$ & 0.35 & 2.5 & 0.50 & 7.5 & 0.35 & 2.5 & 0.35 & 2.5 \\
\hline $80-98$ & 0.35 & 2.5 & 0.50 & 7.5 & 0.40 & 7 & 0.40 & 7 \\
\hline $98-105$ & 0.55 & 10 & 0.55 & 10 & 0.45 & 12 & 0.45 & 12 \\
\hline $105-112$ & 0.55 & 14 & 0.55 & 14 & 0.50 & 14 & 0.50 & 14 \\
\hline $112-119$ & 0.55 & 16 & 0.55 & 16 & 0.52 & 19 & 0.52 & 19 \\
\hline $119-126$ & 0.55 & 18 & 0.55 & 18 & 0.55 & 24 & 0.55 & 24 \\
\hline $126-133$ & 0.55 & 20 & 0.55 & 20 & 0.58 & 29 & 0.58 & 29 \\
\hline $133-145$ & 0.55 & 20 & 0.55 & 20 & 0.63 & 32 & 0.63 & 32 \\
\hline
\end{tabular}

\section{Results}

\section{Feed intake}

Dry matter intake during the first 40 days of pregnancy was not significantly different between treatments nor between litter sizes. Age affected the dry matter intake significantly, when intake was expressed in grams per day, but not when intake was expressed per kilogram metabolic body weight. This is due to the fact that older ewes ( $>2$ years) have about $16 \mathrm{~kg}$ more body weight than ewes of two years old. During mid pregnancy the ewes on treatment $\mathrm{H} 40 \mathrm{C}$ consumed $28 \%$ more dry matter than the ewes on the other treatments. The effect of the treatments and of litter size on intake of total dry matter and dry matter from concentrates are shown in the Figures 1 and 2 . The statistical significance of explanatory variables of the dry matter intake during the last two months of pregnancy expressed in grams per day and in grams per $W^{3 / 4}$ are shown in Table 4 . In contrast to the first months of pregnancy the percentages of variance accounted for were low and the RSD's were high in the last two months of pregnancy, using the model including year, litter size, age, acetonaemia and treatment. The variation between ewes in the last two months of pregnancy was very high. The highest intake $(1.95 \mathrm{~kg})$ was realized by a ewe with a single lamb and the lowest intakes $(0.2 \mathrm{~kg})$ by ewes suffering from acetonaemia.

According to the used feeding strategies the maximum possible intake in the last weeks of pregnancy was about $58 \mathrm{~g} \mathrm{DM} \mathrm{W}^{-3 / 4}$. Except barren ewes and some ewes with singles, all ewes consumed less then this maximum. Also the aimed levels of ME intake (Table 3) were not consumed by the ewes as shown in Figure 3. The statistical analysis of the ME intake showed the same pattern as the dry matter intake, except for the treatment effect. Compared to the control treatment L40C ME intake was higher for treatment L60C (+81 kJ ME W-3/4, SD $=17)$ and treatment $\mathrm{L} 60 \mathrm{C}+\mathrm{P}(+67 \mathrm{~kJ} \mathrm{ME} \mathrm{W-3/4}, \mathrm{SD}=17)$ during the last weeks of pregnan- 


\section{H. EVERTS}

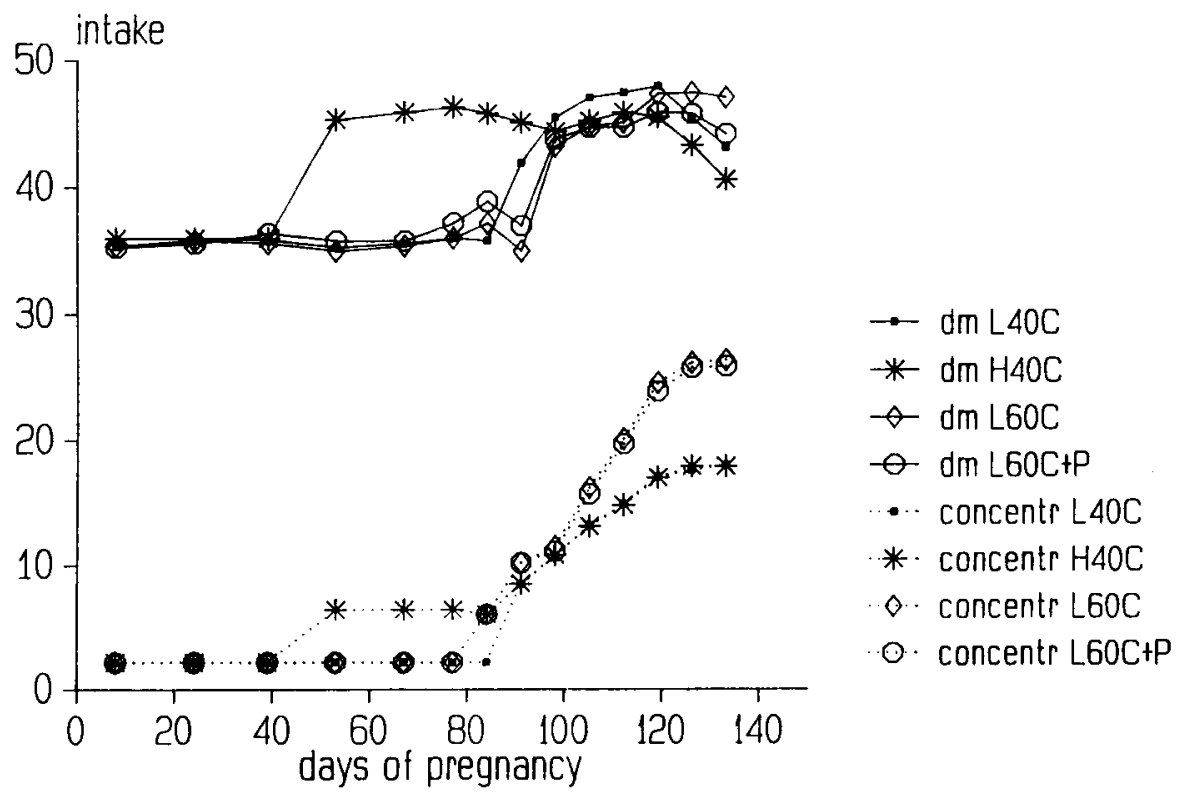

Fig. 1. The effect of treatment on intake during pregnancy of total dry matter and dry matter from concentrate expressed in $\mathrm{g} \mathrm{W}^{-3 / 4}$. Mean values per period are shown for a ewe of mean age and pregnant of a triplet; ewes with acetonaemia are excluded.

Table 4. Effects of year, litter size, age, incidence of acetonaemia (= aceton.) and treatment on dry matter intake during the last two months of pregnancy given as F-values with the statistical significance. The percentage of variance accounted for $(\% \mathrm{Acc}$.) and the residual standard deviation (RSD) of the model are shown.

\begin{tabular}{llllll}
\hline $\begin{array}{l}\text { Period } \\
\text { (days) }\end{array}$ & Effect & & & & \\
\cline { 2 - 5 } & year & litter size & age & aceton. & treatment
\end{tabular}

Dry matter intake expressed in $g d^{-1}$

$\begin{array}{rrrrrrrr}95-101 & -5.55^{* * *} & 3.65^{* *} & 34.63^{* * *} & 0.02^{\mathrm{ns}} & 1.77^{\mathrm{ns}} & 24.8 & 149 \\ 102-108 & 4.41^{* * *} & 5.43^{* * *} & 26.28^{* * *} & 0.31^{\mathrm{ns}} & 1.85^{\mathrm{ns}} & 23.0 & 165 \\ 109-115 & 1.97^{\mathrm{ns}} & 7.69^{* * *} & 15.12^{* * *} & 3.21^{\mathrm{ns}} & 1.91^{\mathrm{ns}} & 19.7 & 172 \\ 116-122 & 1.79^{\mathrm{ns}} & 10.88^{* * *} & 8.80^{* * *} & 8.11^{*} & 0.82^{\mathrm{ns}} & 21.9 & 182 \\ 123-129 & 1.72^{\mathrm{ns}} & 17.61^{* * *} & 2.00^{\mathrm{ns}} & 40.28^{* * *} & 0.99^{\mathrm{ns}} & 34.8 & 202 \\ 130-137 & 3.45^{* *} & 18.84^{* * *} & 0.12^{\mathrm{ns}} & 79.70^{* * *} & 2.44^{\mathrm{ns}} & 44.7 & 240\end{array}$

Dry matter intake expressed in $g W^{-3 / 4}$

\begin{tabular}{rrrrrrrr}
$95-101$ & $13.79^{* * *}$ & $5.31^{* * *}$ & $1.45^{\text {ns }}$ & $1.04 \mathrm{~ns}$ & $3.54^{*}$ & 30.1 & 3.9 \\
$102-108$ & $10.84^{* * *}$ & $8.06^{* * *}$ & $2.26^{\text {ns }}$ & 1.49 ns & $3.86^{*}$ & 29.8 & 4.6 \\
$109-115$ & $4.78^{* * *}$ & $10.65^{* * *}$ & $8.75^{* * *}$ & $6.00^{*}$ & $3.67^{*}$ & 27.4 & 4.9 \\
$116-122$ & $1.63^{\text {ns }}$ & $15.74^{* * *}$ & $13.90^{* * *}$ & $12.13^{* * *}$ & $2.28^{\mathrm{ns}}$ & 30.3 & 5.1 \\
$123-129$ & $3.77^{* * *}$ & $23.70^{* * *}$ & $18.57^{* * *}$ & $47.15^{* * *}$ & $1.47^{\mathrm{ns}}$ & 45.1 & 5.9 \\
$130-137$ & $4.16^{* * *}$ & $25.07^{* * *}$ & $25.02^{* * *}$ & $87.81^{* * *}$ & $2.87^{*}$ & 52.7 & 7.1 \\
\hline
\end{tabular}

*P<0.05, ** $P<0.01, * * * P<0.005$, ns Not significant. 

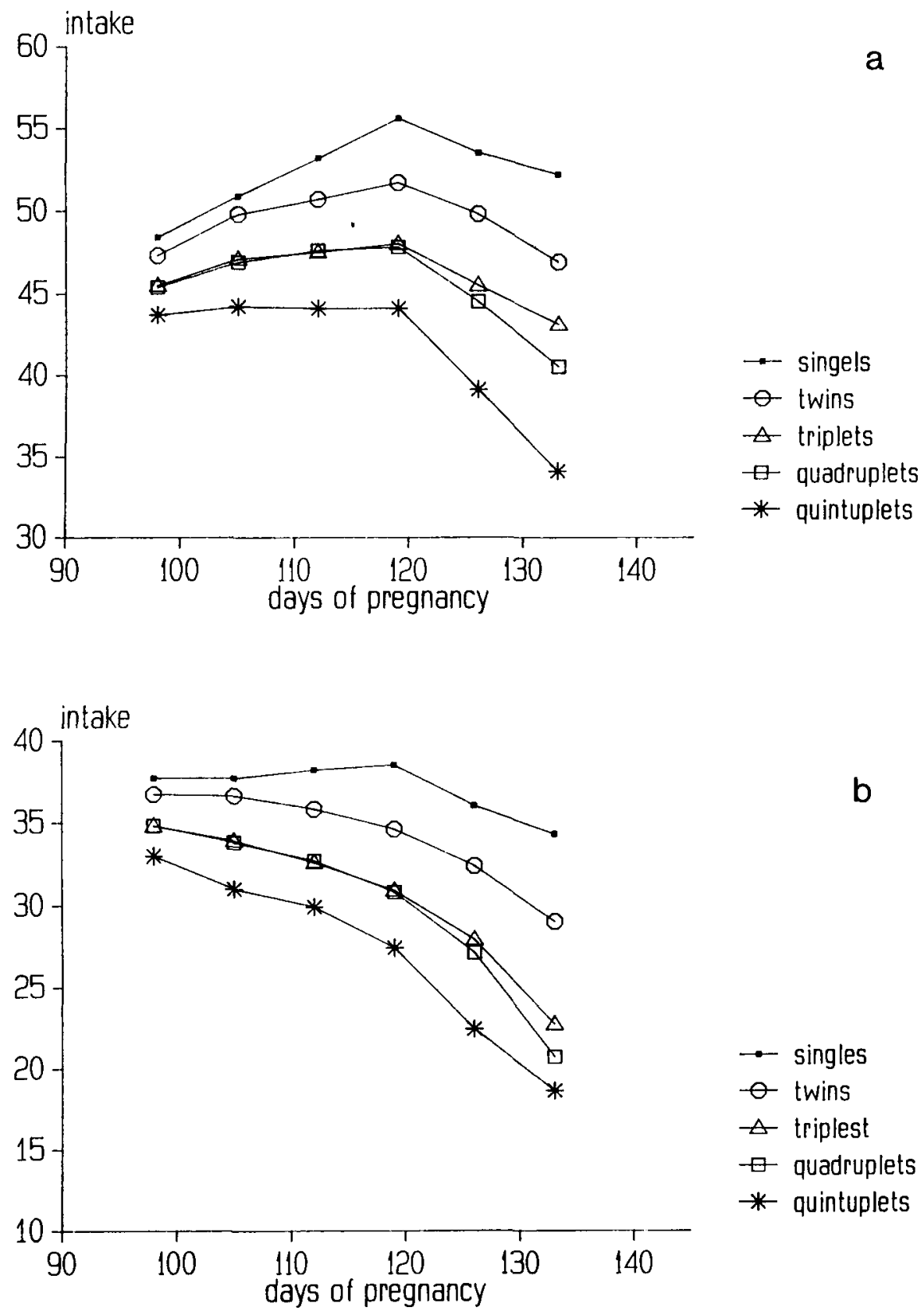

b

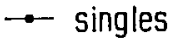

$\theta$ twins

$\triangle$ triplest

$\square$ quadruplets

* quintuplets

Fig. 2. The effect of litter size on intake during pregnancy of total dry matter (a) and dry matter from hay (b) expressed in $W^{-3 / 4}$. Mean values per period are shown for an ewe of mean age on the control treatment L40C; ewes with acetonaemia are excluded. 


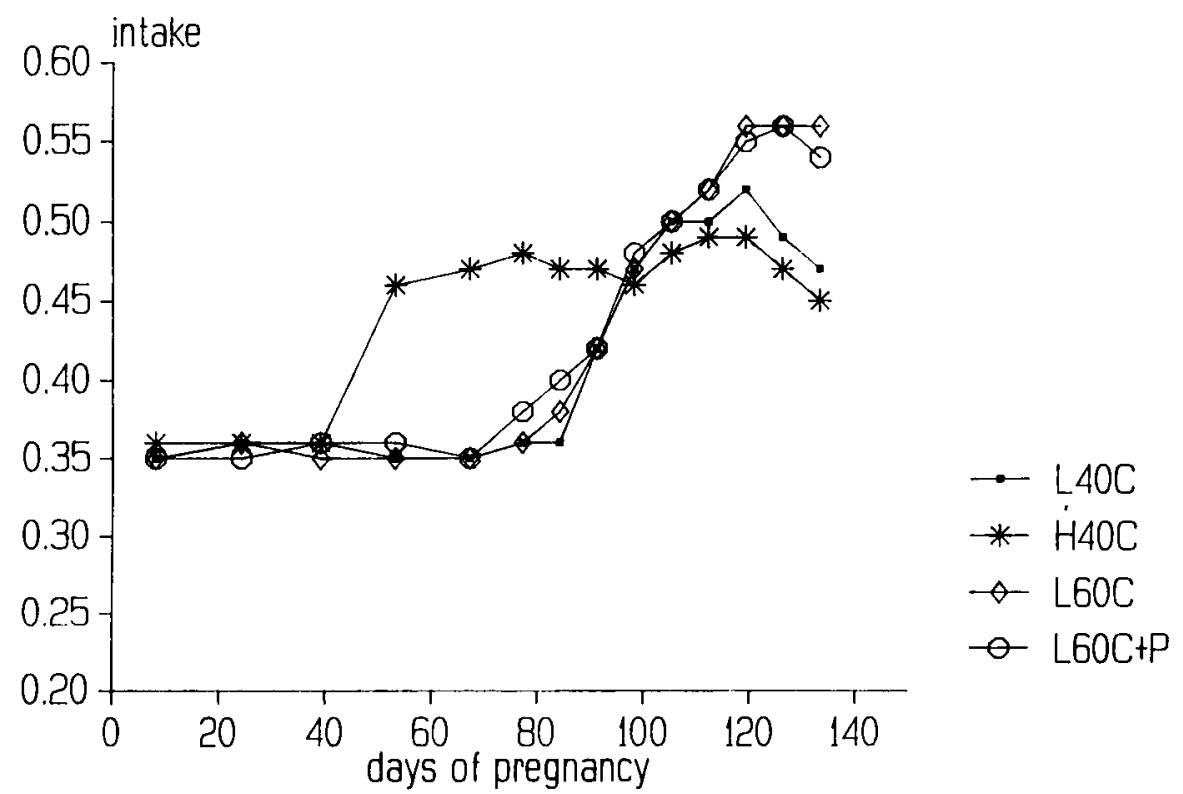

Fig. 3. The effect of treatment on ME intake during pregnancy, expressed in MJ ME W-3/4. Mean values per period are shown for a ewe of mean age and pregnant of a triplet; ewes with acetonaemia are excluded.

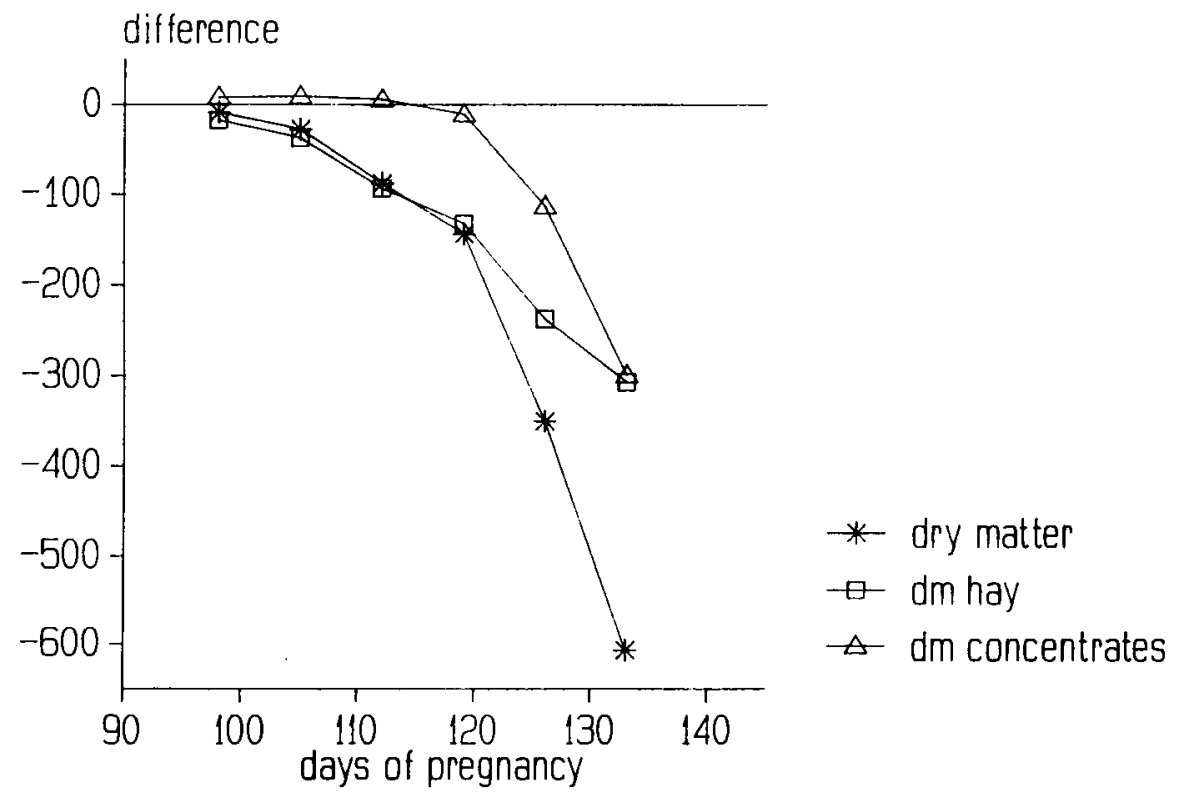

Fig. 4. The effect of acetonaemia on intake during pregnancy of total dry matter, dry matter from hay and dry matter from concentrates in $\mathrm{g} \mathrm{d}^{-1}$ expressed as a difference to healthy ewes. 
cy. The CP intake had the same pattern as the dry matter intake, except for the treatment effect. The $\mathrm{CP}$ intake for treatment $\mathrm{L} 60 \mathrm{C}+\mathrm{P}$ was significantly higher $\left(+1.35 \mathrm{~g} \mathrm{~W}^{-3 / 4}, \mathrm{SD}=0.33\right)$ than for the control treatment $\mathrm{L} 40 \mathrm{C}$ in the last weeks of pregnancy. During day 95 to day 101 of pregnancy dry matter intake ( $g$ $\left.\mathrm{d}^{-1}\right)$ was $168 \mathrm{~g}(\mathrm{SD}=29)$ higher for older ewes. At the end of pregnancy this difference was reduced to $31 \mathrm{~g}(\mathrm{SD}=46)$.

Dry matter intake per $\mathrm{W}^{3 / 4}$ is affected by age at the end of pregnancy. During day 95 to day 101 of pregnancy younger ewes consumed $0.76 \mathrm{~g} \mathrm{DM} \mathrm{W}^{-3 / 4}$ (SD = 0.75 ) more than older ewes and this difference increased to $5.30 \mathrm{~g} \mathrm{DM} \mathrm{W}^{-3 / 4}$ (SD $=1.36$ ) at the end of pregnancy.

Acetonaemia had a significantly negative effect on dry matter intake during the last month of pregnancy. The difference in intake of total dry matter, dry matter from hay and dry matter from concentrates between ewes with and without clinical acetonaemia is shown in Figure 4.

\section{Reproductive performance and incidence of acetonaemia}

Eventually, 208 of the 220 ewes $(95 \%)$ gave birth and in total 679 lambs were born. The mean litter size per lambing ewe was 3.26. For the control treatment L40C, treatment $\mathrm{H} 40 \mathrm{C}, \mathrm{L} 60 \mathrm{C}$ and $\mathrm{L} 60 \mathrm{C}+\mathrm{P}$ the mean litter size was $3.19,3.03,3.54$ and 3.41 , respectively. The differences in litter size between treatments were not statistically significant using the frequency distribution of litter size. Irrespective treatments $3.8 \%$ of the ewes gave birth to a single lamb, 15.9 to a twin, $42.3 \%$ to a triplet, 26.0 to a quadruplet and $12.0 \%$ to a quintuplet.

Average lamb mortality at birth was $9 \%$. During the first 24 hours $2.8 \%$ of the lambs died and in the next six days $0.9 \%$ died. There was no effect of treatment on total lamb mortality (until 7 days after birth). Litter size had a significant effect on total lamb mortality $\left(\chi^{2}=53.5 ; \mathrm{df}=4 ; P<0.001\right)$. For lambs born as single, twin, triplet, quadruplet and quintuplet total mortality was $0,10.6,6.8,9.7$ and $32.0 \%$ respectively.

Because birth weights of lambs within the same litter are dependent, the sum of the birth weight of the lambs born in a litter (= SBW) is analysed. Table 5a shows significant effects of year, litter size, age and treatment on SBW. The estimated effects are shown in Table 5b. Litter size affected SBW the most: mean birth weight lambs born as a single, a twin, a triplet, a quadruplet and a quintuplet was 4.9, 4.0, $3.5,3.0$ and $2.5 \mathrm{~kg}$, respectively. Older ewes $(>2$ years) showed a higher SBW (+ $1.1 \mathrm{~kg}, \mathrm{SD}=0.3)$. Treatment L60C $+\mathrm{P}$ affected SBW significantly $(+1.41 \mathrm{~kg}$, $\mathrm{SD}=0.35$ ).

The incidence of acetonaemia was in ewes with singles and twins $0 \%$, in ewes with triplets $4.5 \%$, in ewes with quadruplets $13 \%$ and in ewes with quintuplets $24 \%$. It was impossible to analyse these results correctly in a statistical model with a binomial distribution and a logit transformation due to a too low incidence of the disease. But the results strongly suggests that litter size and age of the ewe were important factors. The importance of the age of the ewe is also concluded from the observation that only older ewes ( $>2$ years) got acetonaemia. 


\section{H. EVERTS}

Table 5a. F-values and statistical significance of effects of year, litter size, age, clinical acetonaemia (= aceton.) and of treatment on sum of lamb birth weights (SBW), net body weight gain of the ewe (NBWG), gross body weight gain of the ewe (GBWG) and body weight loss at parturition (BWLP). Also the $\%$ of variance accounted for $(\% \mathrm{Acc}$.) and the residual standard deviation (RSD) of the model are shown.

\begin{tabular}{|c|c|c|c|c|c|c|c|}
\hline \multirow[t]{2}{*}{ Parameter } & \multicolumn{5}{|l|}{ Effect } & \multirow[t]{2}{*}{$\%$ Acc. } & \multirow[t]{2}{*}{ RSD } \\
\hline & year & litter size & age & aceton. & treatment & & \\
\hline SBW & $2.77^{*}$ & $81.11^{* * *}$ & $16.52 * * *$ & $0.01^{\mathrm{ns}}$ & $6.41^{* * *}$ & 63.5 & 1.4 \\
\hline NBWG & $26.67^{* * *}$ & $39.26^{* * *}$ & $0.06^{\mathrm{ns}}$ & $14.21^{* * *}$ & $4.96^{* * *}$ & 59.8 & 4.2 \\
\hline GBWG & $22.90^{* * *}$ & $1.13^{\mathrm{ns}}$ & $9.70^{* * *}$ & $16.62^{* * *}$ & $8.04 * * *$ & 43.1 & 4.0 \\
\hline BWLP & $3.97^{*}$ & $65.21^{* * *}$ & $12.60^{* * *}$ & $0.03^{\mathrm{ns}}$ & $0.44 \mathrm{~ns}$ & 57.8 & 3.2 \\
\hline
\end{tabular}

Table 5b. Estimated size of effects of litter size, age, clinical acetonaemia and of treatment. The constant is the estimate for a ewe carrying a single lamb, aging 2 years, not having acetonaemia, on the control treatment $\mathrm{L} 40 \mathrm{C}$ in a mean year.

\begin{tabular}{|c|c|c|c|c|c|c|c|c|c|c|}
\hline \multirow[t]{2}{*}{ Parameter } & \multirow[t]{2}{*}{ Constant } & \multicolumn{4}{|c|}{ Litter size } & \multirow{2}{*}{$\begin{array}{l}\text { Age } \\
>2 y\end{array}$} & \multirow{2}{*}{$\begin{array}{l}\text { Aceton. } \\
\text { yes }\end{array}$} & \multicolumn{3}{|c|}{ Treatment } \\
\hline & & 2 & 3 & 4 & 5 & & & $\mathrm{H} 40 \mathrm{C}$ & $\mathrm{L} 60 \mathrm{C}$ & $\mathrm{L} 60 \mathrm{C}+\mathrm{P}$ \\
\hline SBW & 4.7 & +3.0 & +5.2 & +6.8 & +7.5 & +1.1 & 0.0 & +0.4 & +0.3 & +1.4 \\
\hline NBWG & 9.6 & -3.7 & -8.0 & -10.9 & -15.2 & +0.5 & -4.6 & +1.6 & +2.0 & +3.1 \\
\hline GBWG & 16.9 & +0.2 & -0.5 & +0.8 & -0.6 & +2.7 & -4.7 & +1.6 & +2.2 & +3.9 \\
\hline BWLP & 7.2 & +3.9 & +7.5 & +11.7 & +14.6 & +2.2 & -0.1 & +0.1 & +0.3 & +0.8 \\
\hline
\end{tabular}

${ }^{*} P<0.05,{ }^{* *} P<0.01,{ }^{* * *} P<0.005$, ns Not significant.

\section{Body weight and condition of the ewes}

Mean body weight of the ewes at mating was about $73 \mathrm{~kg}$ and at day 141 of pregnancy about $92 \mathrm{~kg}$. The gross body weight gain (= GBWG), defined and calculated as body weight at day 141 of pregnancy minus body weight at mating was affected by year, age, incidence of acetonaemia and treatment. The net body weight gain (= NBWG) was defined and calculated as body weight after lambing minus the body weight at mating. This NBWG included the mass increase of the udder. NBWG was affected by year, litter size, incidence of acetonaemia and treatment. The body weight loss at lambing ( = BWLP) was affected by year, litter size and age of the ewes.

The F-values and the estimated effects of GBWG, NBWG and BWLP are shown in Table $5 \mathrm{a}$ and $5 \mathrm{~b}$. Mean body condition score at mating was 3.5. Older ewes scored about 0.1 point higher. During the last weeks of pregnancy litter size affected the score significantly. Ewes with twins, triplets, quadruplets and quintuplets scored $0.02(\mathrm{SD}=0.09), 0.16(\mathrm{SD}=0.08), 0.28(\mathrm{SD}=0.09)$ and $0.30(\mathrm{SD}=0.09)$ points lower in body condition than ewes with singles. Ewes with clinical acetonaemia scored about $0.10(\mathrm{SD}=0.06)$ point lower at the end of pregnancy. 


\section{Discussion}

\section{Intake}

The effect of treatment $\mathrm{H} 40 \mathrm{C}$ on the dry matter intake during mid-pregnancy was expected. The level of dry matter intake at the end of pregnancy was relatively low on all treatments. Higher intakes at the end of pregnancy were observed when complete diets were fed (Owen et al., 1980; Dittrich et al., 1980b) or when ewes were shorn (Everts et al., 1988).

Figure 1 shows that ewes on treatment $\mathrm{H} 40 \mathrm{C}$ tended to a lower dry matter intake than the control treatment $\mathrm{L} 40 \mathrm{C}$ at the end of pregnancy. This suggests that the high feeding level in mid-pregnancy depressed feed intake in the last part, but this effect was not significant. The dry matter intake in the last weeks of pregnancy was only significantly affected by treatment L60C. The reason for this higher intake is the higher concentrate allowance. The same effect was expected for treatment L60C + $P$, but the dry matter intake was hardly higher then the control treatment $\mathrm{L} 40 \mathrm{C}$. The hay intake in treatment $\mathrm{L} 60 \mathrm{C}+\mathrm{P}$ was more depressed in the experiment of $1984 / 1985$ with the better quality hay, than in the experiment of $1983 / 1984$ with a moderate quality hay. This suggests a negative effect of the high protein supply on the dry matter intake of treatment $\mathrm{L} 60 \mathrm{C}+\mathrm{P}$. The ewes on treatment $\mathrm{L} 60 \mathrm{C}+\mathrm{P}$ were fed about $34 \%$ above the Dutch DCP requirement (CVB, 1988).

In the last two months of pregnancy the effect of age is dependent of the way of expressing intake. Dry matter intake expressed per $W^{3 / 4}$ is lower for older ewes and this became more significant as pregnancy proceeded, but dry matter intake expressed in grams per ewe per day showed the opposite effect. The age of the ewes is correlated to the body weight of the ewes, but even when intake is expressed per $\mathrm{kg}$ or per $\mathrm{W}^{3 / 4}$ the effect of age exists. An effect of the age of the ewes on feed intake was observed by Tissier et al. (1975).

Body condition of ewes can affect dry matter intake as shown by Stern et al. (1978), but in our experiment the differences in body condition score were too small to prove any effect. It was obvious that ewes with the larger litters scored lower in condition than ewes with small litters. This was also seen from the body weight changes. The effects of climatological conditions and the quality of the hay as observed by Tissier et al. (1975) are in our experiments completely confounded and are presented as effect of the year of experiment.

The substitution rates of concentrates for hay were only calculated over the period where the concentrates allowance was increasing. A mean value of 0.61 for ewes with a triplet was calculated. Berge \& Dulphy (1985) showed with adult wethers that the substitution rate was affected by the quality of the roughage, the composition of the concentrates and the level of concentrates in the ration. Besides these effects also litter size affected the substitution rate as shown by a significant effect of the litter size on the substitution rates in this experiment.

In our experiments the dry matter intake at the end of pregnancy was on a moderate level and the effect of treatments was limited. However, ME intake was positively affected on treatment $\mathrm{L} 60 \mathrm{C}$ and $\mathrm{L} 60 \mathrm{C}+\mathrm{P}$ due to increased concentrates supply. 


\section{H. EVERTS}

\section{Reproductive performance and incidence of acetonaemia}

The litter size and perinatal lamb mortality were not significantly affected by the treatments. The higher lamb birth weight on treatment $\mathrm{L} 60 \mathrm{C}+\mathrm{P}$ did not result in a significantly lower lamb mortality. The positive effect of treatment $\mathrm{L} 60 \mathrm{C}+\mathrm{P}$ on the SBW must be due to the higher protein supply and/or to the less degradable protein. These two factors are completely confounded in the experiment. It can not be due to the higher ME intake at the end of pregnancy, because the positive effect should then also be present in treatment L60C. Positive effects of protein supply on the birth weight of lambs are also observed by Christenson \& Proir (1976).

It was impossible to detect differences in the incidence of acetonaemia between the treatments. This was mainly due to the low frequency of the disease. The ewes with acetonaemia showed a reduced intake due to a decrease in intake both of hay and concentrate. Figure 4 shows a gradually decreasing hay intake and a sharp drop in concentrates intake in the last two weeks. At the end of pregnancy the ratio between dry matter from concentrates and total dry matter intake hardly differed between ewes with and without acetonaemia. However, the problem remains what is cause and what is effect.

\section{Effect of litter size}

From this experiment it can be concluded that dry matter intake decreases at the end of pregnancy. A decrease in dry matter intake at the end of pregnancy was also observed by Dittrich et al. (1980a, b), Orr \& Treacher (1984), Reid (1961), Stern et al. (1978), Tissier et al. (1975) and by Tissier \& Brelurut (1979). Weston (1979) showed effects of pregnancy on the digestive function of ewes: a decrease in rumen liquor volume, residence time of Cr-EDTA in the rumen and organic matter digestion at the end of pregnancy. Gonzalez et al. (1985) observed also a lower digestibility of the organic matter and a higher outflow of non-ammonia-nitrogen from the rumen in pregnant ewes.

Additional to the effect of stage of pregnancy the number of lambs in the uterus affected dry matter intake negatively (Figure 2). This was also shown by Orr et al. (1983), Orr \& Treacher (1984) Reid (1961) and Tissier et al. (1975). Several explanations for the effect of litter size on the intake level and the slope of the decrease of feed intake in the last weeks of pregnancy are possible:

a. The space in the abdomen is limited by the fast growing uterus. A ewe with a quintuplet lost in average about $23 \mathrm{~kg}$ at parturition, while a ewe with a single lamb only $9 \mathrm{~kg}$. However, the correlation between the weight loss at parturition and the decrease in dry matter in the last weeks of pregnancy was low (0.313).

b. Heat stress of ewes with an intact fleece at the end of pregnancy was observed by Austin \& Young (1977) and Russel et al. (1985). Heat stress depressed the feed intake (Alexander \& Williams, 1971). The efficiency of energy utilisation for conceptus growth is low (Rattray, 1974; Robinson et al., 1980) and thus a large number of lambs in the uterus leads to a high heat production. Theoretically it was calculated that the heat production of ewes with singles was $150 \%$ of the minimal heat 
production to maintain body temperature (calculated according to Joyce \& Blaxter, 1961). For ewes with quintuplets this was $172 \%$. Unfortunately the correlation between heat surplus and the decrease in dry matter intake in the last weeks of pregnancy was very low (0.133). From experiments with shearing ewes about 8 weeks before lambing it can be concluded that the level of intake can be increased, but that also in shorn ewes a decrease of intake in the last weeks occurred (Everts et al., 1988).

c. Energy deficit at the end of pregnancy results in energy mobilization and increased levels of free fatty acids in the plasma. Paquay \& Vernaillen (1984) showed a decreased feed intake in an adult sheep when small quantities of oleic acid esters were continously infused intravenously. The theoretically calculated mean energy deficit during the last two weeks of pregnancy and the decrease in intake during the last weeks of pregnancy were correlated $(r=0.487)$. However, the question arises what is first: the energy deficit or the decrease in intake?

d. Forbes (1971) suggested that the estrogens depressed the feed intake in the last phase of pregnancy, especially on concentrates-rich diets. This effect is experimentally tested by Bargeloh et al. (1975) in cows: a treatment with progesterone increased the dry matter intake during the last 6 days before parturition with about $45 \%$. However, also other hormones or ratios between hormones can affect feed intake (N.R.C., 1987).

\section{Conclusion}

Ewes with a large litter size and an intact fleece fed on diet with hay and concentrates have a limited capacity to ingest dry matter at the end of pregnancy. When the amount of concentrates is increased energy intake can be increased with $15 \%$. However, the tested treatments did not affect the incidence of acetonaemia nor perinatal lamb mortality. An increase in crude protein intake combined with a lower degradability of the protein increased lamb birth weight significantly. The litter size is an important factor. It affected lamb birth weight, net body weight gain, body weight loss at parturition, level of intake, the decrease in intake in the last period of pregnancy and the substitution rates of concentrates for hay. Ewes with acetonaemia showed a dramatic decrease in intake in the last weeks of pregnancy.

\section{References}

Alexander, G. \& D. Williams, 1971. Heat stress and development of the conceptus in domestic sheep. Journal of Agricultural Science (Cambridge) 76: 53-72.

Austin, A. R. \& N. E. Young, 1977. The effect of shearing pregnant ewes on lamb birth weights. Veterinary Record 100: 527-529.

Bargeloh, J. F., J. W. Hibbs \& H. R. Conrad, 1975. Effect of prepartal hormone administration on feed intake and mineral metabolism of cows. Journal of Dairy Science 58: 1701-1707.

Christenson, R. K. \& R. L. Prior, 1976. Influence of dietary protein and energy on reproductive performance and nitrogen metabolism in Finn-cross ewes. Journal of Animal Science 43: 1104-1113.

CVB, 1988. Short table on feeding standards for farm animals and nutritive value of feedstuffs. (In Dutch.) Centraal Veevoederbureau in Nederland, Lelystad. p. 14.

Ditrich, A., F. Herzog \& M. Hoffman, 1980a. Untersuchungen zur Futteraufnahme mehrlingtragender 


\section{H. EVERTS}

und lactierender Mutterschafe. 1. Mitteilung: Die Aufnahme an Trockengrünfutter. Tierernährung und Fütterung - Erfahrungen, Ergebnisse Entwicklungen 1980/1981 12: 54-57.

Ditrich, A., J. Wallstabe, R. Fuchs \& M. Hoffman, 1980b. Untersuchungen zur Futteraufnahme mehrlingtragender und lactierender Mutterschafe. 2. Mitteilung: Die Aufnahme an pelletiertem Stroh-konzentrat-Gemisch als Alleinfutter. Tierernährung und Fütterung - Erfahrungen, Ergebnisse, Entwicklungen 1980/1981 12: 57-61.

Everts, H., H. Kuiper \& G. J. Garssen, 1988. Positive effects of shearing of pregnant ewes. Annual report of the Institute for Livestock Feeding and Nutrition Research (IVVO), Lelystad, p. 26-37.

Foot, J. Z. \& A. J. F. Russel, 1979. The relationship in ewes between voluntary food intake during pregnancy and forage intake during lactation and after weaning. Animal Production 28: 25-39.

Forbes, J. M., 1971. Physiological changes affecting voluntary food intake in ruminants. Proceedings of the Nutrition Society 30: 135-142.

Gonzalez, J. S., J. J. Robinson \& C. Fraser, 1985. The effect of physiological state on digestion in the ewe and its influence on the quantity of protein reaching the abomasum. Livestock Production Science 12: 59-68.

Jefferies, B. C., 1961. Body condition scoring and its use in management. Tasmanian Journal of Agriculture 32: 19-21.

Joyce, J. P. \& K. L. Blaxter, 1964. The effect of air movement, air temperature and infrared radiation on the energy requirements of sheep. Britisch Journal of Nutrition 18: 5-27.

NRC, 1987. Predicting feed intake of food-producing animals. Subcommittee on feed intake, National Research Council. National Academy Press, Washington DC, p. 3-12.

Orr, R. J., J. E. Newton \& C. A. Jackson, 1983. The intake and performance of ewes offered concentrates and grass silage in late pregnancy. Animal Production 36: 21-27.

Orr, R. J. \& T. T. Treacher, 1984. The effect of concentrate level on the intake of hays by ewes in late pregnancy. Animal Production 39: 89-98.

Owen, J. B., R. F. Lee, P. M. Lerman \& L. Miller, 1980. The effect of the reproductive state of ewes on their voluntary intake of diets varying in straw content. Journal of Agricultural Science (Cambridge) 94: 637-644.

Paquay, R.\& F. Vernaillen, 1984. Effect of oleic acid esters on food intake in sheep. Canadian Journal of Animal Science 64 (Suppl.): 316-317.

Rattray, P. V., 1974. Energy requirements for pregnancy in sheep. Proceedings of the New Zealand Society for Animal Production 34: 67-77.

Reid, R. L., 1961. Energy requirements of ewes in late pregnancy. In: D. Lewis (Ed.), Digestive physiology and nutrition of the ruminant, p. 198-201. Butterworths, London.

Robinson, J. J., I. McDonald, C. Fraser \& J. G. Gordon, 1980. Studies in reproduction in prolific ewes. 6. The efficiency of energy utilisation for conceptus growth. Journal of Agricultural Science (Cambridge) $94: 331-338$.

Stern, D., J. H. Adler, H. Tagari \& E. Eyal, 1978. Responses of dairy ewes before and after parturition to different nutritional regimes during pregnancy. I. Ewe body weight, uterine contents and lamb birth weight. Annales Zootechnique 27: 312-333.

Tissier, M. \& A. Brelurut, 1979. Utilisation d'un ensilage d'herbe de qualite mediocre par les bebris a la fin de la gestation et au debut de la lactation. Bulletin Technique C.R.Z.V. Theix-I.N.R.A. 35: 59-65.

Tissier, M., M. Theriez \& G. Molenat, 1975. Evolution des quantités d'aliment ingérées par les bebris a la fin de la gestation et au debut de la lactation. Incidences sur leurs performances. Annales de Zootechnique 24: 711-727.

Weston, R. H., 1979. Digestion during pregnancy and lactation in sheep. Annales Recherche Véterinaire 10: $442-444$. 